\title{
Synthesis
}

\section{Accommodating the Challenges of Climate Change Adaptation and Governance in Conventional Risk Management: Adaptive Collaborative Risk Management (ACRM)}

\author{
Bradley May $^{1}$ and $\underline{\text { Ryan Plummer }}^{2,3}$
}

\begin{abstract}
Risk management is a well established tool for climate change adaptation. It is facing new challenges with the end of climate stationarity and the need to meaningfully engage people in governance issues. The ways in which conventional approaches to risk management can respond to these challenges are explored. Conventional approaches to risk management are summarized, the manner in which they are being advanced as a tool for climate change adaptation is described, and emerging themes in risk management and climate change adaption are documented. It is argued that conventional risk management for climate change adaptation can benefit from the insights and experiences of adaptive co-management. A hybrid approach termed adaptive collaborative risk management is thus envisaged that enriches conventional risk management with the critical features of adaptive co-management, i.e., collaboration and adaptation. Adaptive Collaborative Risk Management overcomes some of the challenges with conventional risk management, builds upon and complements other approaches to community climate change adaptation, and innovatively addresses both technical and governance concerns in a single integrated process.
\end{abstract}

Key Words: adaptive collaborative risk management; adaptive co-management; climate change adaptation; climate change governance; risk management

\section{INTRODUCTION}

Governments, businesses, and communities throughout the world are turning to risk management to address climate change adaptation. In 2009 the International Organization for Standardization (ISO) released principles and guidelines for risk management (ISO 31000) with broad applicability to any sector and any type of enterprise (e.g., public, private, community) (International Organization for Standardization 2009). Countries such as Canada, New Zealand, Norway, and Australia have followed earlier releases by the ISO to develop their own standards for risk management and are applying these approaches to climate change adaptation. The World Bank (2009) similarly argues that defining risk management as a priority is an essential starting point for climate change adaptation in Europe and Central Asia. Turning to risk management in response to climate change is logical as it is a generally accepted approach for identifying and quantifying threats and developing control mechanisms to reduce risk to individuals, communities, and society. As Sperling and Szekely (2005) and the National Research Council of the National Academies (2009) point out, the starting point for any adaptation measure is the assessment of existing vulnerability to climate variability and extremes.

At the same time as risk management is being pursued, a core assumption upon which it has been predicated is being challenged. The assumption of stationarity, which refers to the fluctuation of natural systems within a range of variability, has been poignantly declared dead (Milly et al. 2008) or ended (National Research Council of the National Academies 2009). Experiences, management approaches, and techniques designed to deal with past variability therefore offer limited confidence to deal with future conditions (National Research Council of the National Academies 2009, de Loë and Plummer 2010). As a consequence of this 
uncertainty, decision making processes for climate change need to be adaptive and learning oriented (National Research Council of the National Academies 2009). Adaptation processes such as risk management also need to be mainstreamed into practice and incorporated into decision making (Smit and Wandel 2006). For example, The United Nations International Strategy for Disaster Reduction (UN ISDR) (2002) poses the question of how we can increase community participation in developing risk reduction measures (UN ISDR 2002). More recently, van Nieuwaal et al. (2009) argue that climate change requires considering issues of governance.

Risk management is not unique in dealing with uncertainties, questions of how to meaningfully engage participants, or in considering governance issues. Scholars concerned with navigating socialecological systems characterized by complexity and uncertainty have pioneered alternatives to conventional resource management. These alternatives embrace uncertainties, respond to change in an adaptive, learning oriented manner, and stress broad participation in pursuing the dynamic process of sustainability (e.g., Holling and Meffe 1996, Berkes et al. 2003, Gunderson 2003). One specific approach that represents an important innovation in resource management in light of the aforementioned conditions is adaptive co-management (Folke et al. 2002, Armitage et al. 2007, Berkes 2009, Plummer 2009). Adaptive co-management is generally considered to be "a process by which institutional arrangements and ecological knowledge are tested and revised in a dynamic, ongoing, self-organized process of learning by doing" (Folke et al. 2002:20, adopted by Armitage et al. 2007, Plummer and Armitage 2007, Berkes 2009).

There is a pressing need to accelerate the transition of risk management in the direction of participation, learning, and governance. This synthesis paper suggests a new opportunity by integrating conventional risk management with adaptive comanagement. We will summarize conventional risk management and how it is being advanced as a tool for climate change adaptation, identify three emerging themes in risk management and climate change adaptation, namely participatory approaches, co-creation of knowledge, and multiple loop learning and adaptive governance networks, and summarize adaptive co-management. A hybrid approach of adaptive and collaborative risk management (ACRM) is then put forth.
Conclusions reflect upon the potential opportunity of this synergy to enhance the effectiveness of both risk management and governance to lead to effective climate change adaptation.

\section{RISK MANAGEMENT: A TOOL FOR CLIMATE CHANGE ADAPTATION}

Risk management as a structured tool for decision making has had a complex history and there are at least three discernable facets to its foundation. The first facet is the issue of how best to address the question of making choices on technological risk under conditions of uncertainty (Kates and Kasperson 1983). Rowe (1988) presents a hierarchy of risk analysis terminology, modified from his earlier text, which is similar to the definitions used today. His process conceives of risk analysis as being divided into two phases of assessment (risk identification and risk estimation) and management (risk aversion and risk acceptance, with a focus on the tricky question of risk "acceptability"). The second facet is the way in which risk management has been applied to global environmental problem solving in the context of hazards and disaster management (Whyte and Burton 1980) and across a host of environment and health related issues (Fowle et al. 1988). The final facet to its foundation concerns inquiries on social aspects of risk (Krimsky and Golding 1992, Hewitt 1999, Mileti 1999).

Risk assessment practice over time can be categorized as a movement from applied science to professional consultancy to post normal science (Funtowicz and Ravetz 1992). The psychometric paradigm has continued to influence risk-based decision making with its usefulness reemerging for analyzing risk perception and terrorism (Jenkin 2006) at about the same time as a the all-hazards approach to risk management has become the focus of activities such as disaster risk management (e.g. Kohler et al. 2004) and local level risk management (Lavell 2005). In addition, community acceptance of risk and the consideration of trust, liability, and consent (TLC) are important aspects of risk-based decision making (Syme 1995).

Risk research has been conceived and executed in a number of ways. For example, Renn (1992) summarizes these different conceptions, including: the actuarial approach, primarily concerned with risk and insurance (e.g., Kovacs and Kunreuther 
2001, Khanduri and Morrow 2003, Gurenko 2004); the toxicological and epidemiological approach, as used in health and environmental protection research (e.g., Liu et al. 2009); the engineering approach, and traditional probabilistic risk analysis (e.g., Ballantyne 2003); the economic approach, dealing with questions of risk-benefit trade-offs (Tol and Leek 1999, Stern 2006); the psychological approach and social theories of risk, dealing with broader questions of risk tolerance (Taylor-Gooby and Zinn 2006, Singleton et al. 2009); and cultural theories of risk (Lima and Castro 2005, Adeola 2007). Risk management has been further applied to areas such as strategic business planning (see International Association for Impact Assessment 2002). The various approaches have major instrumental and social functions with applicability to policy and decision making and have resulted in the development of valuable techniques that can be applied to the assessment and legitimization of risk reduction strategies in coping with uncertainty. Understandably, the techniques developed are highly specialized, technical, sophisticated, and procedurally complex.

Despite its technical orientation and procedural complexity, risk management has the potential to create a lingua franca at community levels because of its breadth. The various approaches described above all have local scale implications. Mainstreaming evaluative techniques for climate change adaptation is at least partially dependent upon the creation of this common language and processes to make adaptation decisions more easily understood and implemented. How best to use complex and technical risk management in the context of sound climate change adaptation policy has been the subject of international attention (United Nations Development Program 2002, Lim and Spangler-Siegfried 2005). Key to making risk management operational in this context is the sound examination of current and future climate risks, as a precursor to assessing and enhancing overall adaptive capacity. In order to accomplish this task there are an increasing number of related, yet different structured frameworks from which practitioners can choose in their evaluation of climate change adaptation strategies (e.g. Willows and Connell 2003, Fenech and MacLellan 2007, Lynch et al. 2008). All either implicitly or explicitly concern themselves with risk management decision making.

The use of risk management is important for climate change adaptation. In order to address an increasing adaptation deficit, climate science and decision making need to be connected across scales in a more effective process of adaptation, through effective mainstreaming that includes both structural and non-structural measures (Burton 2004). Given its use in a number of different risk contexts, there is the possibility to use it for cross-functional decision making. For instance, communities must consider the impacts of climate change on appropriate water infrastructure design, land use planning, housing development, transportation, and energy production, and emergency and disaster management due to their investment time scales (Hallegatte 2009). Added to this is the growing recognition of a need for effective climate-related decision support (National Research Council of the National Academies 2009). This cross-functional character begs the question: can we conceive of a risk management process that is more collaborative, more inclusive, and ultimately more adaptive?

\section{EMERGING THEMES IN RISK MANAGEMENT AND CLIMATE CHANGE ADAPTATION}

We have described the development of risk management as applied to climate change adaptation. We will now identify three emerging themes in risk management and climate change adaptation.

The first theme emerging in risk management is the need for participatory approaches that genuinely engage actors in deliberative and interactive processes. In risk management and climate adaptation there is international recognition of the need for strategic partnerships in natural hazards risk-based decision making (United Nations International Strategy for Disaster Reduction 2002, Etkin et al. 2004). This has led to the development of such concepts as integrated flood management (World Meteorological Organization 2006) and increasingly to the concept of community based disaster risk management within all-hazards risk management (Shaw and Okazaki 2003, van Aalst et. al. 2008). A number of broader community-based participatory adaptation frameworks have also been developed recently, such as sustainable adaptation and mitigation (Bizikova et al. 2008), participatory integrated assessment (Robinson et al. 2006) and vulnerability and capacity analysis (Twigg 2007). These approaches, either explicitly or implicitly, involve the process of assessing and evaluating risk, and as an extension, adaptation options. For 
example, in the Okanagan Basin of British Columbia in Canada, a participatory integrated assessment approach was adopted through a series of workshops and meetings between participants and researchers to develop a dynamic system model relating to water resource management. In reflecting upon this experience, Langsdale et al. observe that "bringing individuals into a volunteer process is always challenging" (2006:63).

A second theme emerging in risk management emphasizes the co-creation of knowledge and commitment to social learning mechanisms. In their study of how global change has been managed across a number of global environmental issues Clarke et al. (2001) ask: who learns, what is learned, what counts as learning, and to what extent do actors, institutions, and societies learn better management of global environment risks? Pelling et al. (2008) identify the relationship between individual learning, communication pathways, and institutional barriers as a knowledge void in climate change research. In building upon existing works in relation to institutions and social learning, and in relation to environmental risks at international and national scales (e.g., Haas and McCabe 2001, Wynne et al. 2001), they argue that spaces in and between organizations are important pathways for social learning and resources for adaptation. Nilsson and Swartling directly draw upon the social learning literature associated with environmental governance to identify bridging and boundary organizations, shadow systems, and conflicting goals as themes to query if and how "the current architecture of climate governance provides a potential for social learning that could facilitate climate adaptation" (2009:6). Most recently, Tschakert and Dietrich (2010) construct a methodological framework for anticipatory learning and adaptive decision making with attention directed at high poverty and complex livelihood-vulnerability risks.

The construction and functioning of adaptive governance networks is a third theme emerging in risk management related to climate adaptation. Researchers have observed that participatory integrated assessments in whatever form have their challenges, not the least of which is transitioning the "research-policy" interface (Cohen et al. 2006). A recent examination of ten integrated landscape management projects by the International Institute for Sustainable Development (IISD) concluded that "ensuring that project results and products feed directly into decision making processes is a considerable challenge" (Bizikova 2009:17). In one of the most comprehensive documents on climate change adaptation in relation to governance to date, van Nieuwaal et al. (2009:7-8) argue that:

It could thus be stated that adaptation is not only, or particularly, a technical issue, but that it can be characterized as a complex social interaction process and that it should be studied as such. Only then can adaptation to climate change also be regarded as a window of opportunities. Dealing with climate adaptation not only demands a rethink of how we arrange our social-ecological or socio-technical systems but also how we govern them.

\section{ADAPTIVE CO-MANAGEMENT: A GOVERNANCE STRATEGY FOR SOCIAL- ECOLOGICAL SYSTEMS}

As previously identified, social-ecological systems research offers knowledge and experience in dealing with uncertainties, questions of how to meaningfully engage participants, and in considering governance issues. The concept of adaptive co-management was coined in the late 1990 s by the Center for International Forestry Research (CIFOR) (Ruitenbeek and Cartier 2001, CIFOR 2008) and also emerged independently as a new direction for co-management (e.g., Folke et al. 2002, Folke et al. 2003, Olsson et al. 2004a). It brings together adaptive management from applied ecology with co-management from common property resources (Berkes 2009).

Adaptive co-management is conceptualized as "a governance system involving networks of multiple heterogeneous actors across various scales that solve problems, make decisions and initiate actions (Fennell et al. 2008:20; see also Carlsson and Berkes 2005, Berkes 2009, Schultz 2009). It uniquely stresses both vertical and horizontal linking characteristics of collaboration as well as the dynamic learning characteristic of adaptive management (Folke et al. 2005, Armitage et al. 2007, Plummer and Fennell 2009). In so doing, it “...creates an 'adaptive dance' between resilience and change with the potential to sustain complex social-ecological systems" (Olsson et al. 2004a:87). Several scholars have turned their attention to summarizing the core components, main attributes, or features associated with adaptive co- 
management (e.g., Olsson et al. 2004a, Folke et al. 2005, Armitage et al. 2007, Olsson et al. 2007, Plummer and Armitage 2007, Center for International Forestry Research 2008, Armitage et al. 2009, Berkes 2009, Plummer and Fennell 2009, Schultz 2009). These include: pluralism and communication; shared decision making and authority; linkages, levels, and autonomy; and learning and adaptation. In engaging in this reflective and problem solving process, feedback is continuous and fosters the "learning-by-doing" that is indicative of adaptive co-management.

Experiences with adaptive co-management are being gained in several different resource contexts and in addressing several aspects of the environment. These include fisheries, forestry, parks and protected areas, water resources, and wildlife. While the number of associated case studies is still relatively small, the accumulation of these experiences and corresponding analytical efforts are yielding valuable insights. For example, a clearer understanding is emerging about the conditions that contribute to success. These include: small-scale contexts in which the resource system can be relatively well-defined; mutual interests in problem solving by an identifiable set of actors; transparent and identifiable property rights; access to adaptive management measures; commitments to long-term institution building and a supportive policy environment; willingness to embrace different types of knowledge; and presence of champions or key leaders (Armitage et al. 2009).

Despite the enthusiasm and rapidly growing experience, it is imperative to remember that "adaptive co-management is not a governance panacea and will not be appropriate in all cases" (Armitage et al. 2009:100). Some environmental challenges, particularly in the absence of the emerging conditions for success, will overwhelm such novel institutional arrangements (Berkes et al. 2007, Armitage et al. 2009). Adaptive comanagement does not guarantee equity or fairness (Berkes 2009) and in the absence of consideration of multiple ethical perspectives, it "may simply be window dressing for well established dilemmas of power and ultimately livelihoods" (Fennell et al. 2008:12). Finally, and especially relevant here, is the reminder by Berkes (2009) that learning does not always lead to adaptation.

\section{ADAPTIVE COLLABORATIVE RISK MANAGEMENT (ACRM)}

We will now consider how conventional risk management can be modified by incorporating ideas from adaptive co-management. In advancing the hybrid approach of ACRM we describe an illustrative example of a conventional risk management framework (CAN/CSA-ISO 31000), draw attention to two critical features of adaptive co-management (collaboration and adaptation) that offer enrichment, and highlight its benefits and relationship to other community climate change adaptation approaches.

The National Research Council of the National Academies observes that "when predictive certainty is elusive and probabilistic information is all that is available, decision making can benefit from an 'uncertainty management' framework" (2009:20). Canadian communities, for example, are increasingly turning to structured risk management for informed decision making and option analysis (Noble et al. 2005). The Canadian Standards Association (CSA) revisited their Standard for effective risk management (CSA-Q850-97) (CSA 1997) and in 2010 adopted without modification Standard ISO 31000 (CSA 2010). CAN/CSA-ISO 31000 is used here as an illustrative example of conventional risk frameworks as it represents international best practice. It also represents the successor risk management framework that Canadian communities were being encouraged to follow for climate change adaptation (Noble et al. 2005, Bruce et al. 2006).

The scope of the Standard is set broadly:

\section{This International Standard can be used by any public, private or community enterprise, association, group or individual. Therefore, this International Standard is not specific to any industry or sector (Canadian Standards Association 2010:15).}

The Standard consists of three main elements. The first element sets forth eleven principles for managing risk. The second outlines the framework in which risk management occurs. It involves five components: mandate and commitment, design of framework for managing risk, implementing risk management, monitoring and review of the framework, and continual improvement of the 
framework. The third element directly connects to the framework and concerns the implementation of risk management through a specific risk management process. The core of this process (see Figure 1) is an iterative series of steps that are performed as warranted, and that include establishing the context, risk assessment (risk identification, risk analysis, risk evaluation), and risk treatment. The activities of communication and consultation as well as monitoring and review are continuous processes around the steps.

Collaboration is the first critical feature of adaptive co-management that offers enrichment to conventional risk management. In conventional risk management stakeholder consultation is emphasized. For example, risk communication and consultation is a continuous activity in CAN/CSA-ISO 31000 understood as follows:

Communication and consultation are continual and iterative processes that an organization conducts to provide, share or obtain information and to engage in dialogue with stakeholders (2.13) regarding the management of risk (2.1). NOTE 1. The information can relate to the existence, nature, form, likelihood (2.19), significance, evaluation, acceptability and treatment of the management of risk. NOTE 2. Consultation is a two-way process of informed communication between an organization and its stakeholders on an issue prior to making a decision or determining a direction on that issue. Consultation is: a process which impacts on a decision through influence rather than power; and an input to decision making, not joint decision making (Canadian Standards Association 2010:18).

As explicitly written in this definition, consultation in conventional risk management is narrowly defined and specifically precludes both sharing power and/or joint decision making.

Collaboration in the context of adaptive comanagement emphasizes the linking or connecting of actors into a process of exploring a shared interest and pooling resources to address a problem with a degree of power sharing and shared decision making. Adaptive co-management encourages extension beyond partnerships (see Plummer and
FitzGibbon 2004 for the distinction) and has a well established history of stressing the inclusion of diverse and conflicting interests (pluralism), representation across scales (linkages) and the need for communicative processes that permit interaction and deliberation (e.g., Schusler et al. 2003, Olsson et al. 2004b, Plummer and FitzGibbon 2004, Folke et al. 2005). With due recognition for the range of forms within adaptive co-management arrangements, “...interrogating adaptive co-management involves a critical examination of the extent to which alternative governance approaches result in, or develop, decision making processes that reflect true partnerships, and that devolve power to local resource users and communities" (Armitage et al.2007:8, Berkes 2007; Armitage et al. 2009). Enriching conventional risk management in this manner is consistent with the need for participatory approaches that genuinely engage actors in the deliberative and interactive processes that have been identified. In this manner it builds upon emerging recent community-based participatory adaptation frameworks such as sustainable adaptation and mitigation (Bizikova et al. 2008) and participatory integrated assessment (Robinson et al. 2006). While the value of collaboration versus consultation could be realized when risk management is initiated by public or private entities, it is most appropriate/ acutely evident in the application of risk management by a community enterprise, association or group. At these scales collective decisions by actors are required in response to risks of a cross-functional character and therefore need to be emphasized in approaches such as integrated flood management (WMO 2006) and all-hazards risk management (Shaw and Okazaki 2003, van Aalst et al. 2008).

Adaptation is the second critical feature of adaptive co-management that offers enrichment to conventional risk management. In conventional risk management an emphasis is placed on continuous monitoring and review. For example, in CAN/CSAISO 31000 monitoring and review occur as a both a step in the risk management framework as well as a continuous activity in implementing risk management. Although presented together, monitoring is defined in CAN/CSA-ISO 31000 as "continual checking, supervising, critically observing or determining the status in order to identify change from the performance level required or expected" while review is an "activity undertaken to determine the suitability, adequacy and effectiveness of the 
Fig. 1. Adaptive collaborative risk management (adapted from CAN/CSA-ISO 31000 2010)

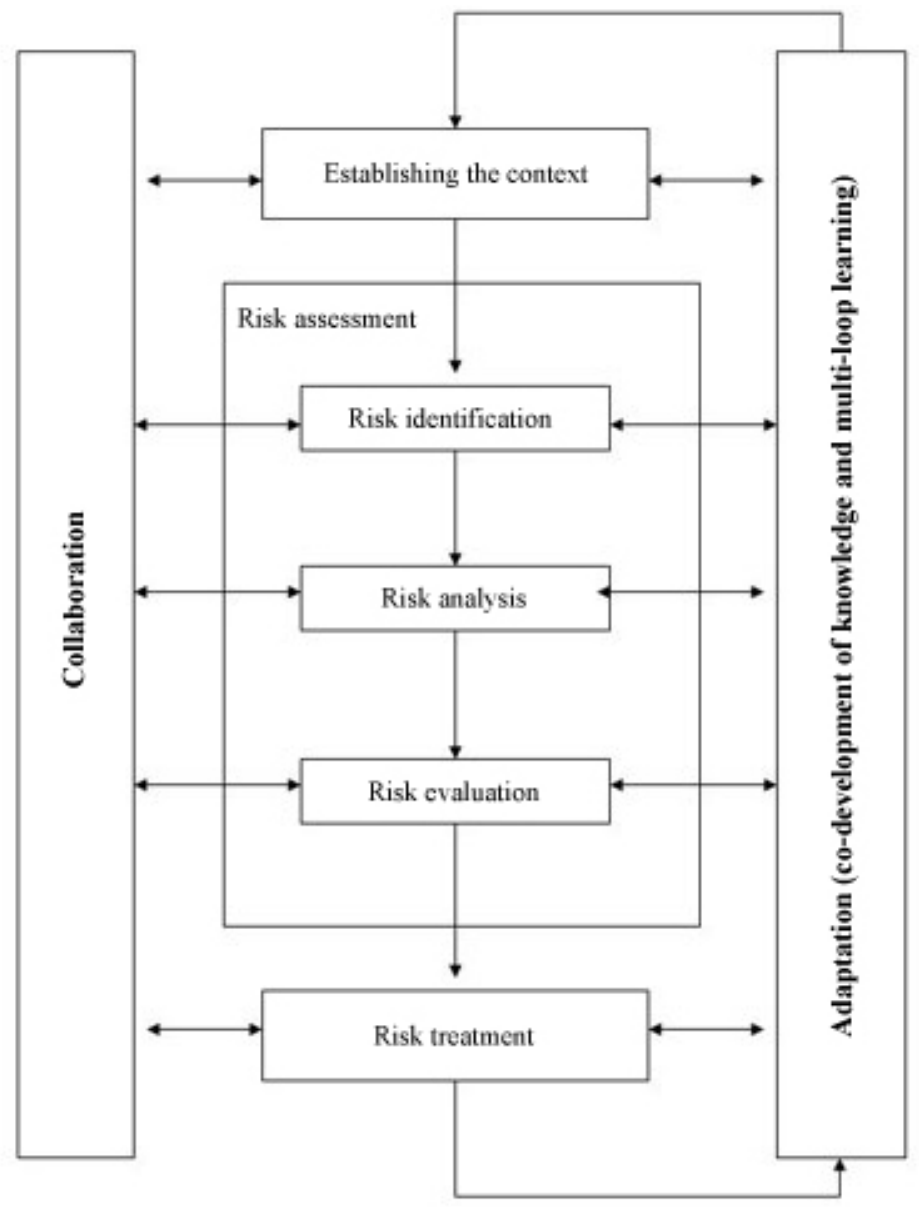

subject matter to achieve established objectives" (CSA 2010:21). It is further specified in CAN/CSAISO 31000 that:

Monitoring and review processes should encompass all aspects of the risk management process for the purposes of: ensuring that controls are effective and efficient in both design and operation; obtaining further information to improve risk assessment; analyzing and learning lessons from events (including nearmisses), changes, trends, successes and failures; detecting changes in the external and internal context, including changes to risk criteria and the risk itself which can require revision of risk treatments and priorities; and identifying emerging risks (CSA 2010:34).

Adaptive management stresses the criticality of learning in the context of uncertainty to enhance both environmental policies and practices (Lee 1993, Gunderson et al. 1995, Armitage et al. 2007). In drawing upon the adaptive management narrative, adaptive co-management, explicitly focuses on "...linking collaborative efforts with systematic learning" and in this way involves a process of mutual development and knowledge sharing (Armitage et al. 2007:9, Plummer and FitzGibbon 2007). The dynamism and outcomes of learning associated with adaptive co-management are illuminated through a multiple loop learning framework (Plummer and FitzGibbon 2007, 
Armitage et al. 2008, Berkes 2009). Single loop learning involves addressing errors that are evident from established routines. Double loop learning corrects errors by making adjustments to values and policies. Triple loop learning seeks to correct errors by addressing or designing governance protocols and norms. Moreover, the need to take a learning based approach in adaptive co-management relating to the monitoring process is stressed by Cundill and Fabricius (2009). Enriching conventional risk management in this way is consistent with the emerging theme of co-development of knowledge and commitment to social learning mechanisms. Efforts associated with adaptive co-management offer a solid starting point to respond Clarke et al. 's (2001) questions concerning learning and global environmental risks. Considerable benefits may be gained by applying insights developed in adaptive co-management to risk management, as the potential for social learning and the inadequacy of existing learning tools have been identified respectively by Nilsson and Swartling (2009) as well as Tschakert and Dietrich (2010).

Figure 1 illustrates how the risk management process set forth by CSA/ISO 31000 (2010) could be modified by incorporating two critical features of adaptive co-management. Enriching conventional risk management in these ways also fundamentally enhances its potentiality with regard to the critical issue of employing an intervention or governance strategy, identified as an emerging theme. Adaptive co-management, which brings together the collaborative and adaptive narratives in natural resource management, navigates and nurtures resilience, and ultimately sustains complex socialecological systems (Berkes et al. 2003, Folke et al. 2005, Olsson et al. 2006, Armitage et al. 2007, Plummer 2009, Schultz 2009). The Centre for International Forestry Research makes clear the opportunities for drawing upon adaptive comanagement in the context of climate change. They observe:

Although climate change issues were just a faraway twinkle in the eyes of the original $A C M$ researchers, the relevance of $A C M$ results to climate change adaptation has become increasingly clear. ... ACM researchers have produced tools, methods and conceptual frameworks that can contribute significantly to efforts to adapt to climate change and perhaps to efforts to mitigate it (Center for International Forestry Research 2009).

Movement of conventional risk management in this direction offers several advantages. For instance, the nature of risk transference and driving forces toward more mega disasters (Etkin 1999) can be explored during ongoing collaboration with stakeholders. Consideration of the way in which hierarchies for coping with threats from natural hazards are "nested" from individuals to communities to government (Newton 1995) can be examined in a structured fashion by those most affected, via a learning process of collective decision making. The multiple loop learning process also addresses known challenges to risk management such as the dichotomy between the greenhouse gas emission reduction mental models of policy makers and citizens (Sterman 2008), differences in perceived adaptive capacity (Grothmann and Patt 2005), and the building of trusted communication for resilience (Longstaff and Yang 2008). Handmer and Dovers (1996) in their discussion of resilience and sustainable development, observe that "traditional" risk management has been perceived and utilized by existing bureaucracies, authorities and power bases with scant attention being paid to stakeholder involvement, in the search for technical solutions. Much has changed in the intervening years. ACRM brings together technical and social aspects and ensures collaboration, as opposed to consultation and communication, and co-development of knowledge and shared learning, as opposed to monitoring and review. ACRM resonates soundly with calls from those studying risk management, especially in the context of climate change. For example, it responds to van Nieuwaal et al.'s (2009) arguments for the need to study and deal with adaptation to climate change as a complex social-ecological issue that requires rethinking our approach to governance. It also speaks to the dual challenges outlined by Tschakert and Dietrich (2010) of understanding adaptation as a process and overcoming the inadequacy of learning tools.

\section{CONCLUSION}

Successful climate change adaptation requires careful consideration of technical and social dimensions. Risk management is part of a comprehensive suite of tools for climate change 
adaptation with international and national standards (e.g., CAN/CSA-ISO 31000) being developed to assist governments, businesses, and communities. The benefits of an "uncertainty management framework" or risk management process are being advanced and communities are turning to these approaches (Noble et al. 2005, Bruce et al. 2006; National Research Council 2009). Risk management and climate change adaptation are not unique in dealing with uncertainty or the emerging themes of participation, social learning, and governance.

We have argued that the transition of risk management in the direction of participation, learning, and governance can be accelerated with insights from adaptive co-management. More specifically, considerable opportunities exist for conventional risk management to be enhanced by incorporating the critical features of collaboration and adaptation from adaptive co-management, especially for community enterprises, associations or groups using such frameworks for climate change adaptation. To envisage these synergies we accordingly modified the CAN/CSA-ISO 31000 Standard for risk management, which is the international benchmark for risk management as well as the risk approach being advanced for community climate change adaptation in Canada (see Noble et al. 2005, Bruce et al. 2006). The resulting hybrid approach is termed Adaptive Collaborative Risk Management (ACRM). ACRM overcomes some of the challenges associated with traditional risk management, builds upon other approaches to community climate change adaptation, and is positioned to more robustly respond to the complex and uncertain challenges of climate change. ACRM may also offer innovation in other risk management contexts and this is an important avenue for future conceptual inquiry.

van Nieuwaal et al. (2009) argue that dealing with climate change requires us to think about not only our social-ecological or social-technical systems, but also the manner in which they are governed. ACRM opens the possibility of integrating these technical and social aspects in one process for climate change adaptation that has the flexibility to change over time as circumstances warrant. It also permits the integration of risk-based decision making and the social context in which decisions are made. While the conceptual opportunities suggested with ACRM draw upon grounded experiences with adaptive co-management, it requires empirical testing next.
Responses to this article can be read online at: http://www.ecologyandsociety.org/voll6/iss 1/art47/ responses/

\section{Acknowledgments:}

The authors would like to express their gratitude to the ESRC, NERC, DEFRA and University of East Anglia, as well as the International Human Dimensions Programme on Global Environmental Change for the opportunities to present preliminary thoughts at their respective international expert workshop and conference. Our appreciation is also extended to Don MacIver, Asa Swartling, Derek Armitage, and Ian Burton for their collegial discussions and exchanges that positively shaped this work. The assistance of Ashley Chynoweth, Chris Luckhart, and Alison Powell in the preparation of the manuscript is also very much appreciated. Support for Ryan Plummer's research in the area of adaptive co-management is provided by the Social Sciences and Humanities Research Council of Canada and the Chancellor's Chair for Research Excellence at Brock University.

\section{LITERATURE CITED}

Adeola, F. O. 2007. Nativity and environmental risk perception: an empirical study of native-born and foreign-born residents of the USA. Research in Human Ecology 14(1):13-25.

Armitage, D. R., F. Berkes, and N. Doubleday. 2007. Introduction: moving beyond comanagement. Pages 1-18 in D. Armitage, F. Berkes, and N. Doubleday, editors. Adaptive co-management: collaboration, learning and multi-level governance. University of British Columbia Press, Vancouver, British Columbia, Canada.

Armitage, D., M. Marschke., and R. Plummer. 2008. Adaptive co-management and the paradox of learning. Global Environmental Change 18:86-98.

Armitage, D. R, R. Plummer, F. Berkes, R. I. Arthur, A. T. Charles, I. J. Davidson-Hunt, A. P. Diduck, N. Doubleday, D. S. Johnson, M. Marschke, P. McConney, E. Pinkerton, and E. Wollenberg. 2009. Adaptive co-management for social-ecological complexity. Frontiers in Ecology and the Environment 7(2):95-102. 
Ballantyne, D. 2003. Multi-hazard risk assessments of water systems, elements in common with seismic, security, and other risk studies. Proceedings of the Third US-Japan Workshop on Water Systems Seismic Practices (Los Angeles, 2003). [online] URL: http://www.mmiengineering.com/pdf/ Ballantyne2003JWWAAWWARF.pdf

Berkes, F. 2007. Adaptive co-management and complexity: exploring the many faces of comanagement. University of British Columbia Press, Vancouver, British Columbia, Canada.

Berkes, F. 2009. Evolution of co-management: role of knowledge generation, bridging organizations and social learning. Journal of Environmental Management 90:1692-1702.

Berkes, F., D. Armitage, and N. Doubleday. 2007. Synthesis: adapting, innovating, evolving. Pages 308-327 in D. Armitage, F. Berkes, and N. Doubleday, editors. Adaptive co-management. University of British Columbia Press, Vancouver, British Columbia, Canada.

Berkes, F., J. Colding, and C. Folke. 2003. Navigating social-ecological systems: building resilience for complexity and change. Cambridge University Press, Cambridge, UK.

Bizikova, L. 2009. Challenges and lessons learned from integrated landscape management (ILM) projects, International Institute for Sustainable Development (IISD). [online] URL: http://www.iisd. org/pdf/2009/challenges lessons ilm.pdf.

Bizikova, L., T. Neale, and I. Burton. 2008. Canadian communities' guidebook for adaptation to climate change: including an approach to generate mitigation co-benefits in the context of sustainable development. First edition. Environment Canada and the University of British Columbia, Vancouver, British Columbia, Canada. [online] URL: http://www.forestry.ubc.ca/LinkClick.aspx? fileticket $=x$ sexCSatHjo\%3D\&tabid $=2455 \& \mathrm{~m}$ $\mathrm{id}=5415$ \&language $=$ en-US.

Bruce, J. P., I. D. M. Egener, and D. Noble. 2006. Adapting to climate change: a risk-based guide for Ontario municipalities. Report submitted to Natural Resources Canada Climate Change Impacts and Adaptation Programme. Natural Resources Canada, Ottawa. [online] URL: http://adaptation.nrcan.gc.ca/ projdb/pdf/176a e.pdf
Burton, I. 2004. Climate change and the adaptation deficit. Occasional Paper 1. Adaptation and Impacts Research Group (AIRG), Meteorological Services of Canada, Environment Canada, Toronto, Ontario, Canada.

Canadian Standards Association. (CSA). 1997. Risk management: guideline for decision-makers. Reaffirmed 2009. Canadian Standards Association, Etobicoke, Ontario, Canada.

Canadian Standards Association (CSA). 2010. Risk management - principles and guidelines. National Standard of Canada, Mississauga, Ontario, Canada. CAN/CSA-ISO 31000-10, January.

Carlsson, L., and F. Berkes. 2005. Co-management: concepts and methodological implications. Journal of Environmental Management 75:65-76.

Center for International Forestry Research (CIFOR). 2008. Adaptive collaborative management can help us cope with climate change. Information Brief No. 13, July. [online] URL: http://www.cifor. cgiar.org/publications/pdf files/Infobrief/013-infobrief. pdf

Center for International Forestry Research (CIFOR). 2009. ACM and beyond: climate change adaptation. [online] URL: http://www.cifor.cgiar.org/ acm/beyond/climate-adaptation.htm.

Clarke, W. C., J. Jager, and J. van Eijndhoven. 2001. Managing global environmental change: an introduction to the volume. Pages 3-19 in W. Clark, and N. Dickson, editors. Learning to manage global environmental risks a comparative history of social responses to climate change, ozone depletion and acid rain. The MIT Press, Cambridge, Massachusetts, USA.

Cohen, S. J., D. Neilsen, S. Smith, T. Neale, B. Taylor, M. Barton, W. Merritt, Y. Alila, P. Shepherd, R. McNeill, J. Tansey, J. Carmichael, and S. Langsdale. 2006. Learning with local help: expanding the dialogue on climate change and water management in the Okanagan region, British Columbia, Canada. Climatic Change 75:331-358.

Cundill, G., and C. Fabricius. 2009. Monitoring in adaptive co-management: toward a learning based approach. Journal of Environmental Management 90(11):3205-3211. 
de Loë, R., and R. Plummer. 2010. Climate change, adaptive capacity and governance for drinking water in Canada. in D. Armitage, and R. Plummer, editors. Adaptive capacity and environmental governance. Springer-Verlag, Berlin, Germany.

Etkin, D. 1999. Risk transference and related trends: driving forces towards more megadisasters. Environmental Hazards 1:69-75.

Etkin, D., E. Haque, L. Bellisario, and I. Burton. 2004. An assessment of natural hazards and disasters in Canada: A report for decision-makers and practitioners. Environment Canada and Public Safety and Emergency Preparedness Canada, Ottawa, Ontario, Canada.

Fenech, A., and J. MacLellan. 2007. Rapid assessment of the impacts of climate change: building past and future histories of climate extremes. Linking climate models to policy and decision-making. Environment Canada, Toronto, Ontario, Canada.

Fennell, D., R. Plummer, and M. Marschke. 2008. Is adaptive co-management ethical? Journal of Environmental Management 88(1):62-75.

Folke, C., S. Carpenter, T. Elmqvist, L. Gunderson, C. S. Holling, B. Walker, J. Bengtsson, F. Berkes, J. Colding, K. Danell, M. Falkenmark, M. Moberg, L. Gordon, R. Kaspersson, N. Kautsky, A. Kinzig, S. A. Levin, K. G. Mäler, L. Ohlsson, P. Olsson, E. Ostrom, W. Reid, J. Rockström, S. Savenije, and U. Svedin. 2002. Resilience and sustainable development: building adaptive capacity in a world of transformations. Environmental Advisory Council to the Swedish Government Scientific Background Paper. Ministry of the Environment, Stockholm, Sweden.

Folke, C., J. Colding, and F. Berkes. 2003. Synthesis: building resilience and adaptive capacity in social-ecological systems. Pages 252-387 in F. Berkes, J. Colding, and C. Folke, editors. Navigating social-ecological systems. Cambridge University Press, Cambridge, UK.

Folke, C., T. Hahn, P. Olsson, and J. Norberg. 2005. Adaptive governance of social-ecological systems. Annual Review of Environment and Resources 30:441-473.
Fowle, C. D., A. P. Grima, and R. E. Munn, editors. 1988. Information needs for risk management. Environmental Monograph no. 8. University of Toronto, Institute for Environmental Studies, Toronto, Ontario, Canada.

Funtowicz, S. O., and J. R. Ravetz. 1992. Three types of risk assessment and the emergence of postnormal science. Pages 251-273 in S. Krimsky, and D. Golding, editors. Social theories of risk. Praeger, Westport, Connecticut, USA.

Grothmann, T., and A. Patt. 2005. Adaptive capacity and human cognition: the process of individual adaptation to climate change. Global Environmental Change 15:199-213.

Gunderson, L.H. 2003. Adaptive dancing: interactions between social resilience and ecological crises. Pages 33-52 in F. Berkes, J. Colding, and C. Folke, editors. Navigating socialecological systems. Cambridge University Press, Cambridge, UK.

Gunderson, L. H., C. S. Holling, and S. S. Light, editors. 1995. Barriers and bridges to the renewal of ecosystems and institutions. Columbia University Press, New York, New York, USA.

Gurenko, E. N. 2004. Building effective catastrophe insurance programs at the country level: a risk management perspective. Chapter 8 in A. Mathur, I. Burton, and M. van Aalst, editors. An adaptation mosaic: a sample of the emerging work bank work in climate change adaptation, final draft. World Bank Global Climate Change Team, Washington, D.C., USA.

Haas, P. M., and D. McCabe. 2001. Amplifiers or dampeners: international institutions and social learning in the management of global environmental risks. Pages 323-348 in P. M. Haas, S. Jasanoff, and G. Rochlin, editors. Learning to manage global environmental risks, 1: a comparative history of social responses to climate change, ozone depletion and acid rain. MIT Press, Cambridge, Massachusetts, USA.

Hallegatte, S. 2009. Strategies to adapt to an uncertain climate future. Global Environmental Change 19:240-247.

Handmer, J. W., and R. S. Dovers. 1996. A typology of resilience: rethinking institutions for sustainable 
development. Organization and Environment 9 (4):482-511.

Hewitt, K. 1999. Regions of risk: hazards, vulnerability and disasters. Pearson-Longman, London, UK.

Holling, C. S., and G. K. Meffe. 1996. Command and control and the pathology of natural resource management. Conservation Biology 10(2):328-337.

International Association for Impact Assessment (IAIA). 2002. Impact assessment in the corporate context. Business and industry series No.1. May.

International Organization for Standarization (ISO). 2009. Risk management - principles and guidelines. ISO 31000:2009(E), November. ISO, Geneva, Switzerland.

Jenkins, C. M. 2006. Risk perception and terrorism: applying the psychometric paradigm. Homeland Security Affairs II(2). [online] URL: http://www.hs aj.org/?fullarticle $=2.2 .6$

Kates, R. W., and J. X. Kasperson. 1983. Comparative risk analysis of technological hazards (a review). Proceedings, National Academy of Sciences 80:7027-7038.

Khanduri, A. C., and G. C. Morrow. 2003. Vulnerability of buildings to windstorms and insurance loss estimation. Journal of Wind Engineering and Industrial Aerodynamics 91:455-467.

Kohler, A., S. Julich, and L. Bloemertz. 2004. Guidelines, risk analysis, a basis for disaster risk management. Section 42, Governance and democracy. Deutsche Gesellschaft fur Technische Zusammenarbeit, Eschborn, Germany.

Kovacs, P., and H. Kunreuther. 2001. Managing catastrophic risk: lessons from Canada. ICLR Research Papers 13. Institute for Catastrophic Loss Reduction (ICLR). [online] URL: http://www.iclr.o rg/images/Managing Catastrophic Risk.pdf.

Krimsky, S., and D. Golding. 1992. Social theories of risk. Praeger, Westport, Connecticut, USA.

Langsdale, S., A. Beall, J. Carmichael, S. Cohen, and C. Forster. 2006. Exploring water resources futures with a system dynamics model. in S. Cohen, and T. Neale, editors. Participatory integrated assessment of water management and climate change in the Okanagan Basin, British Columbia, Vancouver. Environment Canada and University of British Columbia, Vancouver, British Columbia, Canada.

Lavell, A. 2005. Local level risk management concept and practices. Coordination Center for the Prevention of Natural Disasters in Central America (CEPREDENAC) and the United Nations Development Programme (UNDP), Guatemala.

Lee, K. 1993. Compass and gyroscope: integrating science and politics for the environment. Island Press, Washington, D.C., USA.

Lim, B., and Spanger-Siegfried, editors. 2005. Adaptation policy frameworks for climate change: developing strategies, policies and measures. United Nations Development Programme. Cambridge University Press, Cambridge, UK.

Lima, M. L., and P. Castro. 2005. Cultural theory meets the community: worldviews and local issues. Journal of Environmental Psychology 25:23-35

Liu, Y., B. Zheng, Q. F. Wei Meng, and Y. Wang. 2009. Risk assessment and management of arsenic in source water in China. Journal of Hazardous Materials 170:729-734.

Longstaff, P. H., and S. Yang. 2008. Communication management and trust: their role in building resilience to "surprises" such as natural disasters, pandemic flu, and terrorism. Ecology and Society 13(1):3. [online] URL: http://www.ecology andsociety.org/vol13/iss 1/art3/.

Lynch, A. H., L. Tryhorn, and R. Abramson. 2008. Working at the boundary: facilitating interdisciplinary in climate change adaptation research. Bulletin of the American Meteorological Society 89:169-179.

Mileti, D. 1999. Disasters by design: a reassessment of natural hazards in the United States. National Academies, Washington, D.C., USA.

Milly, P. C .D., J. Betancourt, M. Falkenmark, D. Lettenmaier, and R. J. Stouffer. 2008. Stationarity is dead: whither water management. Science 319 (5863):573-574.

National Research Council of the National Academies (NRC). 2009. Informing decisions in a 
changing climate. Panel on Strategies and Methods for Climate-Related Decision Support. National Academies, Washington, D.C., USA.

Newton, J. 1995. An assessment of coping with environmental hazards in northern Aboriginal communities. Canadian Geographer 39(2):112-120.

Nilsson, A. E., and A. G. Swartling. 2009. Social learning about climate adaptation: global and local perspectives. Stockholm Environment Institute, Stockholm, Sweden.

Noble, D., J. Bruce, and M. Egener. 2005. An overview of the risk management approach to adaptation to climate change in Canada. Global Change Strategies International (GCSI), Ottawa, Ontario, Canada.

Olsson, P., C. Folke, and F. Berkes. 2004a. Adaptive co-management for building resilience in socialecological systems. Environmental Management 34:75-90.

Olsson, P., C. Folke, and T. Hahn. 2004b. Socialecological transformation for ecosystem management: the development of adaptive co-management of a wetland landscape in southern Sweden. Ecology and Society 9(4):2. [online] URL: http://www.ecolo gyandsociety.org/vol9/iss4/art2/.

Olsson, P., L. H. Gunderson, S. R. Carpenter, P. Ryan, L. Lebel, C. Folke, and C. S. Holling. 2006. Shooting the rapids: navigating transitions to adaptive governance of social-ecological systems. Ecology and Society 11(1):18. [online] URL: http:/ /www.ecologyandsociety.org/vol11/iss1/art18/.

Olsson, P., C. Folke, V. Galaz, T. Hahn, and L. Schultz. 2007. Enhancing the fit through adaptive co-management: creating and maintaining bridging functions for matching scales in the Kristianstads Vattenrike Biosphere Reserve Sweden. Ecology and Society 12(1):28. [online] URL: http://www.ec ologyandsociety.org/vol12/iss1/art28/.

Pelling, M., C. High, J. Dearing, and D. Smith. 2008. Shadow spaces for social learning: A relational understanding of adaptive capacity to climate change within organizations. Environment and Planning A 40:867-884.
Plummer, R. 2009. The adaptive co-management process: an initial synthesis of representative models and influential variables. Ecology and Society 14(2):24. [online] URL: http://www.ecolog yandsociety.org/vol14/iss2/art24/.

Plummer, R., and D. R. Armitage. 2007. Charting the new territory of adaptive co-management: a Delphi study. Ecology and Society 12(2):10. [online] URL: http://www.ecologyandsociety.org/vol12/ iss2/art10/.

Plummer, R., and D. Fennell. 2009. Managing protected areas for sustainable tourism: prospects for adaptive co-management. Journal of Sustainable Tourism 17(2):149-168

Plummer, R., and J. E. FitzGibbon. 2004. Some observations on the terminology in cooperative environmental management. Journal of Environmental Management 70:63-72.

Plummer R, and J. E. FitzGibbon. 2007. Connecting adaptive co-management, social learning and social capital through theory and practice. Pages 38-61 in D. Armitage, F. Berkes, and N. Doubleday, editors. Adaptive co-management: learning, collaboration and multi-level governance. University of British Columbia Press, Vancouver, British Columbia, Canada.

Renn, O. 1992. Concepts of risk: a classification. Chapter 3 in S. Krimsky, and D. Golding, editors. Social theories of risk. Praeger, London, UK.

Robinson, J., M. Bradley, P. Busby, D. Conor, A. Murray, B. Sampson, and W. Soper. 2006. Climate change and sustainable development: realizing the opportunity. Ambio 35:2-9.

Rowe, W.D. 1988. An anatomy of risk. Reprint edition. Krieger, Malabar, Florida, USA.

Ruitenbeek, J., and C. Cartier. 2001. The invisible wand: adaptive co-management as an emergent strategy in complex bio-economic systems. Center for International Forestry Research Occasional Paper 34. [online] URL: http://www.cifor.cgiar.org/ publications/pdf files/OccPapers/OP-034.pdf.

Schultz, L. 2009. Nurturing resilience in socialecological systems: lessons learned from bridging 
organizations. Stockholm University, Stockholm, Sweden.

Schusler, T. M., D.J. Deker, and M. J. Pfeffer. 2003. Social learning for collaborative natural resource management. Society and Natural Resources 15:309-326.

Shaw, R., and K. Okazaki, editors. 2003. Sustainability in grass-roots initiatives: focus on community based disaster management. United Nations Centre for Regional Development Hygo Office. [online] URL: http://www.hyogo.uncrd.or.jp/ publication/pdf/Report/CBDMPDF/CBDM report. pdf

Singleton, G., H. Herzog, and S. Ansolabehere. 2009. Public risk perspectives on the geologic storage of carbon dioxide. International Journal of Greenhouse Gas Control 3:100-107.

Smit, B., and J. Wandel. 2006. Adaptation, adaptive capacity and vulnerability. Global Environmental Change 16:282-292.

Sperling, F., and F. Szekely. 2005. Disaster risk management in a changing climate. Discussion Paper prepared for the World Conference on Disaster Reduction on behalf of the Vulnerability and Adaptation Resource Group (VARG) (Kobe, 2005). Reprint with addendum on conference outcomes. Washington, D.C., USA.

Sterman, J. D. 2008. Risk communication on climate: mental models and mass balance. Science 322:532-533.

Stern, N. 2006. The Stern review on the economics of climate change. Cambridge University Press, Cambridge, UK.

Syme, G. J. 1995. Community acceptance of risk: trust, liability and consent. Pages 31-40 in P. Heinrichs, and R. Fell, editors. Acceptable risks for major infrastructure. Balkema, Rotterdam, the Netherlands.

Taylor-Gooby, P., and J. O. Zinn. 2006. Current directions in risk research: new developments in psychology and sociology. Risk Analysis 26 (2):397-411.

Tol, R. S. J., and P. M. Leek. 1999. Economic analysis of natural disasters. Chapter 12 in T. E.
Downing, A. J. Olsthoorn, and R. S. J. Tol, editors. Climate, change and risk. Routledge, London, UK.

Tschakert, P., and K.A. Dietrich. 2010. Anticipatory learning for climate change adaptation and resilience. Ecology and Society 15(2):11. [online] URL: http://www.ecologyandsociety.org/vol15/iss2/ art11/.

Twigg, J. 2007. Vulnerability and capacity analysis. Tools for mainstreaming disaster risk reduction. Guidance Note 9. International Federation of Red Cross and Red Crescent Societies, ProVention Consortium, Geneva, Switzerland.

United Nations Development Program, (UNDP). 2002. A climate risk management approach to disaster reduction and adaptation to climate change. UNDP Expert Group Meeting, Integrating Disaster Reduction with Adaptation to Climate Change (Havana, 2002). [online] URL: http://www.undp.org/ cpr/disred/documents/wedo/icrm/riskadaptationintegrated. pdf

United Nations International Strategy for Disaster Reduction (UN ISDR). 2002. Living with risk: a global review of disaster reduction initiatives. InterAgency Secretariat of the International Strategy for Disaster Reduction, Geneva, Switzerland.

van Aalst, M. K., T. Cannon, and I. Burton. 2008. Community level adaptation to climate change: the potential role of participatory community risk assessment. Global Environmental Change 18 (1):165-179.

van Nieuwaal, K., P. Driessen, T. Spit, and C. Termeer. 2009. A state of the art governance literature on adaptation to climate change: towards a research agenda. Report Number kfc 003/2009. Dutch National Research Programme Knowledge for Climate, Utrecht University, Wageningen University, Netherlands.

Whyte, A. V., and I. Burton, editors. 1980. Environmental risk assessment. SCOPE report 15. Wiley, New York. New York, USA.

Willows, R. I., and R. K. Connell, editors. 2003. Climate adaptation: risk, uncertainty and decisionmaking. UKCIP Technical Report. United Kingdom Climate Impacts Programme (UKCIP), Oxford, UK. 
World Bank. 2009. Adapting to climate change in Europe and Central Asia. The Office of the Chief Economist of ECA. [online] URL: http://go.worldb ank.org/7OOC1E7AU0.

World Meteorological Organization (WMO). 2006. Social aspects and stakeholder involvement in integrated flood management. Associated Programme on Flood Management, WMO No. 1008. WMO, Geneva, Switzerland.

Wynne, B., P. Simmons, C. Waterton, P. Hughes, and S. Shackley. 2001. Institutional cultures and the management of global environmental risks in the United Kingdom. Pages 93-113 in W.C. Clark, J. Jager, J. van Eijndhoven, and N. M. Dickson, editors. Learning to manage global environmental risks. MIT Press, Cambridge, Massachusetts, USA. 